\title{
キャンパス緑地の保全・活用を目的とした大学の地域連携組織に関する研究 - 金沢大学角間の里山自然学校の活動実態と連携体制の進展過程から- \\ THE ORGANIZATION ESTABLISHED TO PRESERVE AND UTILIZE THE GREEN OPEN SPACE IN CAMPUS WITH THE PARTNERSHIP OF UNIVERSITY AND COMMUNITY
}

Case study on the activities and the progress of Satoyama nature school:

Kakuma of Kanazawa university

$$
\text { 高橋里 佳*, 小松 尚** }
$$

\section{Satoka TAKAHASHI and Hisashi KOMATSU}

This paper aims to clarify the roles and challenges of the university's organization established to preserve and utilize green space in the campus in partnership with the neighbors, analyzing the actual conditions of activities and the progress of the collaborative formation by "Satoyama Nature School : Kakuma of Kanazawa University"(the School). The findings are as follows.

1. It is evaluated highly that the School have progressively organized the activities and the relationship with neighbors.

2. "Satoyama Mate" was organized by neighbors during the activities, and has led them currently. Enhancing to empower neighbors and citizens is one of the important roles of collaborative organization, even if it is established by a university.

3. The full-time staff and the stronghold "Kakuma no Sato" have also played an important and an effective role to deepen the relationship.

4. Regarding with the notice by "Satoyama Mate", the way to position collaborative organization with neighborhood as well as green space in the university's long-range plan and the organizational structure is one of the important challenges.

5. In addition, since the School has been substantially operated by the subsidies from Ministry of Education so far, there is also a concern of how operational fund would be secured continually.

keywords: partnership of university and community, campus, green open space, preservation, utilization 大学・地域連携,キャンパス, 緑地, 保全, 活用

1. はじめに

\section{1-1. 研究の背景}

大学キャンパスは大学のみならず、周辺住民にとっても貴重な財 産であり、特にキャンパス内の緑地は、地域の緑地としての役割も 果たしている。しかし、18 歳人口の減少や国立大学の法人化等に伴 い、大学は自立的かつ戦略的な経営が急務になっているが、キャン パス資源のマネジメントに割り当てられる財源や人材は限られてい

る。現在はその多くが建物のマネジメントに向けられており、キャ ンパス緑地のマネジメントは十分に行えていないのが一般的である。 その一方で近年になって、大学が地域住民や地域コミュニティと 協働で地域づくりに取り組む事例が各地で見られるようになってい るが、その中でキャンパスの、そして地域の公共空間でもありえる 緑地の保全・活用を大学側が地域住民に呼びかけ、協働で行う取り 組みがある。大学と地域住民とをつなぐ役割として、大学側が活動 連携組織を立ち上げ、活動を主導的に支援する体制を整えているの である。

\section{1-2. 研究の目的・方法}

本研究では、金沢大学角間の里山自然学校（以下自然学校）を事 例に、キャンパス緑地の保全・活用を目的にした地域と大学の連携 活動の実態とそれに応じて段階的に変容・進展する自然学校と地域 住民や地域団体の連携体制を分析することで、連携の中核を担う大
学の地域連携組織のあり方や役割、課題について論じる。

まず、自然学校の成果報告書 ${ }^{1 \sim 3)}$ や関連資料の分析、自然学校 関係者へのヒアリング調查等により、設立から現在（2007 年度時点。 以下同様）までの活動実態を把握する。次に、自然学校が主催・協 力・支援する活動を整理し、地域住民や地域団体との連携状況を把 握する。さらに、連携関係にある地域住民や地域団体に対して連携 活動に関するヒアリング注1) を行い、自然学校との活動についての 評価を把握する。そしてこれらから、大学と地域の協㗢の取り組み のプラットフォームとなる大学の地域連携組織としてのあり方を考 察する。

\section{1-3. 研究対象}

金沢大学は 1978 年に総合移転の方針を決定し、1980 年に総合移 転地を角間地区に決定している（表 1)。角間地区は、金沢市街地 に隣接した角間丘陵地の一角に位置しており、古くから多くの動植 物が生息する里山として、市民に親しまれてきた場所である（図 1)。 総合移転の第 II 期キャンパス開発の際、1997 年にキャンパスの一 部を里山ゾーン注2) に指定し、キャンパスの自然環境の保全・修復 に配慮しながら、地域に開かれたキャンパスづくりを目指している。 その中で自然学校は、金沢大学角間キャンパス内の緑地を教育・ 研究に利用するだけではなく、地域住民の学習活動、自然体験の場 として開放することを目的として 1999 年に発足した。キャンパス

\footnotetext{
本論文は既発表論文 1 を大幅に加筆・修正したものである。

*タイプ・エービー 修士(環境学)

** 名古屋大学大学院環境学研究科都市環境学専攻 准教授・博士 (工学)
}

Type A/B, M. Environmental Studies

Assoc. Prof., Graduate School of Environmental Studies, Nagova Univ., Dr. Eng. 


\begin{tabular}{|c|c|c|}
\hline 西暦 & & 角間キャンパス整備計画事業 \\
\hline $\begin{array}{l}1978 \\
1980\end{array}$ & & $\begin{array}{l}\text { 評議会で総合移転（200ha 構想）の方針を決定 } \\
\text { 評議会で総合移転地を「角間地区」に決定 }\end{array}$ \\
\hline 1984 & & 「総合移転整備事業建設工事起工式」を挙行 \\
\hline 1989 & 第 I 期 & 文学部・法学部・経済学部棟及び付属図書館が完成 \\
\hline 1992 & 計画事業 & 理学部棟・教育学部棟が完成 \\
\hline 1995 & 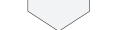 & 「総合移転第 I 期計画事業完成記念式典」を挙行 \\
\hline 1997 & & $\begin{array}{l}\text { キャンパスの一部を「里山ヅーン」（自然園 12ha } \\
\text { 環境保全自然研究林 } 62 \mathrm{ha} \text { ) に指定 }\end{array}$ \\
\hline 1998 & 第 II 期 & 第 II 期整備工事起工式 \\
\hline 2003 & 計画事業 & 自然科学 1 号館完成 \\
\hline 2004 & $(\sim 2008$ 年) & $\begin{array}{l}\text { ベンチャー・ビジネス・ラボラトリー、ハードラボ、 } \\
\text { 自然科学本館完成 }\end{array}$ \\
\hline 2005 & & 自然科学 2.3 号館、自然科学系図書館、角間の里完成 \\
\hline
\end{tabular}

内の緑地をフィールドにして、地域住民との協働活動による緑地の 保全・活用を目的として大学が立ち上げた点に特徴がある。

\section{2. 本研究の位置づけ}

\section{2-1. 大学における地域連携組織}

近年、日本の大学では地域社会との接点を持ち、地域とともに空 間・機能の再生や環境保全、経済再生、担い手育成など様々なテー マでまちづくり活動を実践し、同時に教育研究を行う組織注3) を立 ち上げる事例が生まれている。その特徴は、文科省等の資金援助に より始められ、学生と教員で構成されているケースが多い。そのた め、運営資金の不安定さとスタッフ不足を問題点として挙げている 組織が多い。

\section{2-2. キャンパス緑地の保全 - 活用を進める他事例との比較}

一方、大学キャンパスに目を向けると、キャンパスの開発や移転 をきっかけとして、キャンパス整備や活用を主目的として地域住民 との協働活動を実施する組織が立ち上がっている。1989 年に新キャ ンパスを開設した龍谷大学は、2003 年に教員らにより設立された 保全の会により、地域住民と協働してキャンパス内の「龍谷の森」 の保全活動を行なっている。九州大学では、2005 年からの総合移 転に伴い新キャンパスのマスタープラン (2001 年) に緑地の保全や、 地元ボランティアを導入した里山管理などが明記されている。

この 2 事例に共通した特徴として、新キャンパスの開発がきっか けとなり始まっていることが挙げられる。また龍谷大は大学教員ら が活動を開始したのに対し、九州大はマスタープラン自体に組み込 まれているという違いが見られる。

本研究が取り上げる金沢大学でも、キャンパス移転後に里山ゾー ンとして保全が意図された緑地を対象にして、具体的な保全活用 活動が始まった。その活動内容は上述の 2 大学のそれと共通点もあ り、キャンパス緑地の保全活用を目的にした活動として定着してき ていると考えられる。一方、金沢大学では自然学校という地域連携 組織が設立されている点に特色があり、4 章以降で詳述するが、自 然学校の活動に参画する地域住民が徐々に組織化され、自然学校と 共同プロジェクトを立ち上げるなど、自然学校を中心にした地域住 民や地域団体との実質的な連携関係が構築されているとみなせる。 よって、この 10 年近くの活動実態や連携体制の進展を分析するこ とにより、国内では先進的な大学の地域連携組織の役割や課題を実 証的に検証できる事例と考えられる。

\section{2-3. 既往研究}

大学と地域の連携に関する既往研究では、小篠ら ${ }^{4)}$ がキャンパ

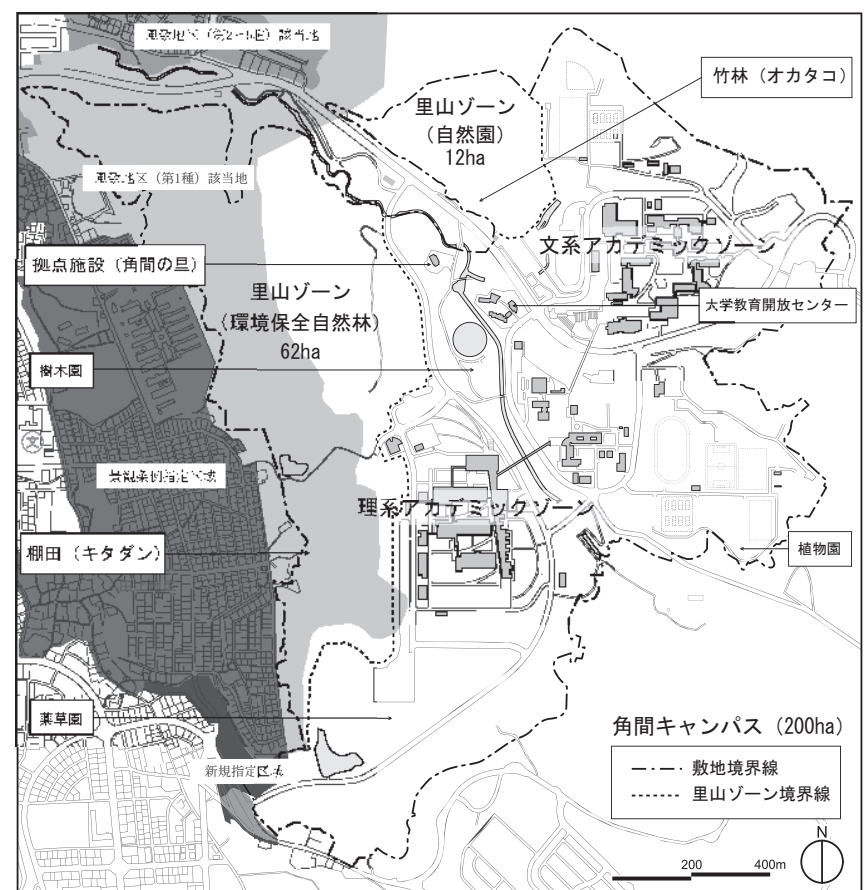

図 1 金沢大学角間キャンパスとその周辺地区

スマスタープランから抽出される特徴的な計画視点の意味を物的要 素を扱う視点から考察している。大学と地域との連携の枠組みを明 らかにしており、I . 広範囲で、複合的な計画視点を持つこと、II . 合 意形成プロセスとキャンパスマスタープランに連動する計画システ ムを構築すること、III . 計画自体に計画の双方向性、計画の連動、 改訂のプロセス、計画関与という性質を持たせること、が必要だと 指摘している。

渡辺ら ${ }^{5 \sim 7)}$ は、アメリカにおける地域連携組織のなかでも特に、住宅 供給やコミュニティ開発の分野でコミュニティ・ベースで大きく発展して いる非営利組織について着目し、その実態を明らかにしている。その非営 利組織の中でも建築面での技術支援を行なっているのがコミュニティ・デ ザイン・センターであり、その組織基盤、専従専門家スタッフの有無、財 政によって大きく 5 つタイプに分類している。5つのタイプの中でも、全 体の約 $40 \%$ と一番多いタイプが大学ベース型であり、地域活動を支援す る組織には大学が関与しているケースが多いという。また遠藤 ${ }^{8)}$ は、コミュ ニティ・デザイン・センターの事例分析から、大学に基盤を置くデザイン センターの可能性と課題を明らかにしている。大学に基盤を置いているた め、ノウハウや情報の蓄積があり、民間が対象に出来ないような地域を対 象にできることや、大学と地域との接点を設けることで、教員・学生にとっ ての教育・研究の機会拡大につながることが有効であるとしている。

李 $^{9)}$ は、フィラデルフィアにおいて大学と地域の一体的整備を 積極的に進めている事例より、大学が主体となる大学まち再生の手 法を明らかにしている。大学施設を広範囲に点在させることで地域 を一体的に整備していることや、周辺地域組織と連携して大学施設 と地域機能を融合させていることを挙げている。

中野ら ${ }^{10 \cdot 11)}$ は、キャンパス資源の整備・運営を学生や教職員と 地域住民らの協働で行っている大学へのアンケート調查によって、 その実態を把握している。その中で、課題をきっかけに学内外のグ ループが連携し始めていることや新しい活動グループを育成してい ることを挙げている。 
表 2 自然学校発足までの流れ

\begin{tabular}{|c|c|c|}
\hline & \multicolumn{2}{|c|}{ 金沢大学の動向 } \\
\hline & $\begin{array}{l}\text { 金沢大学創立 } 50 \text { 周年 } \\
\text { 記念事業の計画段階 }\end{array}$ & 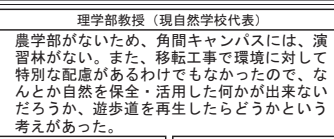 \\
\hline 1999 年 & & 8 \\
\hline 7 月 & $\begin{array}{l}\text { 田上第五土地区画整理組合へ } \\
\text { 協力を依頼 }\end{array}$ & 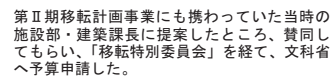 \\
\hline 8 月 & $\begin{array}{l}\text { 地元住民、施設部建築課長らとともに、く } \\
\text { キャンハハス内を歩き、意見交換 }\end{array}$ & $\begin{array}{l}\text { 第1回の自然学校活動 } \\
\end{array}$ \\
\hline 10 月 & 文科省より予算がおりる （生涯学習政策局 & 調査研究費) \\
\hline 11月 & 自然学校設置の概要及び要項が全学委員会で & 承認される（第 8 回研究·環境委員会） \\
\hline 12 月 & 委員会立ち上げ （学長 : 名誉顧問、副学長 & : 顧問) \\
\hline
\end{tabular}

よって本研究の独創性は、わが国の大学が設置した先進的な地域 連携組織の到達点と課題を明らかにするために、キャンパス緑地の 保全・活用を目的とした活動の実態と地域住民や地域団体との連携 体制の変容や進展を実証的に分析、考察する点にあると考えている。

\section{3. 角間の里山自然学校の概要}

\section{3-1. 発足当時と現在までの経緯}

自然学校代表者へのヒアリングにより、発足経緯について把握し た (表 2 )。発足当時、金沢大学は創立 50 周年の記念事業の計画中 であったと同時に総合移転の第 II 期事業を行っていた。金沢大学で は農学部がないため演習林を持たず、新キャンパス内の里山も活用 されないままになっていた。そのため、自然学校代表が大学施設部 に対して遊歩道整備などといった緑地の活用計画を提案し、文部科 学省への予算申請がきっかけとなり、1999 年 11 月の自然学校発足 へと至った。このように自然学校が発足に至った背景には、大学の 総合移転事業で造成されたキャンパスに残る自然環境の回復目的や 創立 50 周年事業との関連が大きい。

また発足に先立って、元土地所有者を含む地元住民らと大学関係 者、工事関係者によるキャンパス内の散策が行われ、意見交換がな されている。その後、学内の全学委員会で自然学校の設置が承認さ れ、運営委員会が組織された。運営委員会には学内の教員、事務官 だけではなく、多くの学外メンバー注4) が参加していた。

初年度（1999 年度）は試行期間として、ワークショップ等により、 地域住民の意見を聞き入れ、活動へと反映させていったほか、自然 観察会や保全活動、地元小学校の授業協力も行っている。

その後、活動が進むにつれて、2000 年度からは自然学校の趣旨 に賛同し、定期的に活動に参加する学内外の支援者をボランティア として登録し始めている。自然学校の発足以降、熱心な参加者が目 立つようになり、特に角間の里山の元所有者を含む地元住民などは 里山の保全活動などを指導したり、植物や昆虫に詳しい住民が他の 参加者を指導する様子が目立っていた。自然学校はそれを受けて、 より積極的な活動が出来るようにと組織されたものである。

さらに、ボランティア登録者のなかでより積極的に活動に関わ りたいと考える参加者が 2 年間の議論を行い、2002 年度からは会 員制の「角間の里山メイト」(発足当初約 100 名。以下里山メイト) が正式発足している。2007 年度現在では、約 250 名が登録してい る 注5)。会員からは年会費 2000 円を徵収し、保険料や通信費、グルー

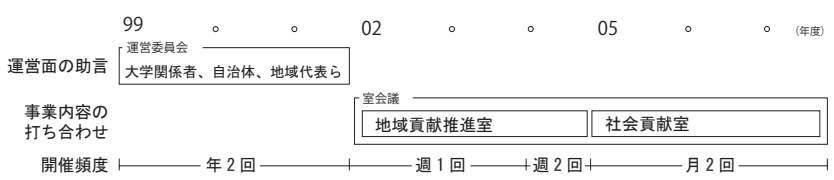

図 2 自然学校業務に関する支援体制の変化

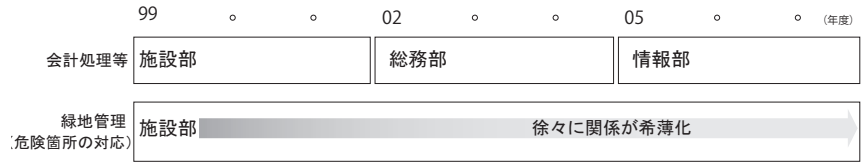

図 3 事務局との関わり

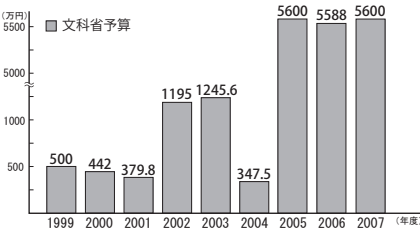

図4 運営資金

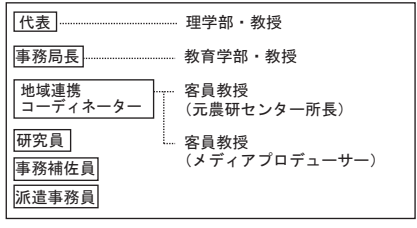

図 5 スタッフ構成
プ活動費などに使用されている。

また、2001 年度から定期活動日が設けられた。活動日は毎月第 2 ・ 4 土曜日の午前中で、申し込久不要で誰でも参加可能である。

\section{3-2. 大学事務局との連携}

自然学校の発足当初より、大学事務局が会計や活動フィールドの 改善等の面で協力している。発足当初の 1999 年度から 2001 年度ま では、施設部が自然学校の会計等を担当していた。施設部との関係 は 2002 年度以降も続いており、自然学校の活動により発見された 里山ゾーンの危険箇所の対応などを施設部が行っている。しかし、 自然学校側が施設部に出向かなくなったことや大学の法人化に伴い 組織構成が変わってしまったこと等の理由から、最近では協力関係 は薄れている（図 $2 \cdot 3$ )。

このことは、当初はキャンパスの開発工事で荒れた緑地の回復を 目的に大学事務局が自然学校の運営を支援していたが、現在では自 然学校と前述の里山メイトなどとの連携体制が活動や運営を自立的 に実施できるようになったためとも解釈できる。

\section{3-3. 運営資金}

自然学校は、主に文部科学省の予算によって運営されている（図 4) 注 6)。1999 年度から 2001 年度は文部科学省生涯学習政策局・ 調查研究費により実施された。2002 年度から 2004 年度は文部科学 省地域貢献特別推進事業経費を受けて実施された「地域貢献特別 事業」の一環として支えられた。2005 年度からは、文部科学省特 別教育研究経費（連携融合）（5 力年）により「里山プロジェクト」 が始まり、このプロジェクトの 1 つとして自然学校の活動が位置づ けられている。

\section{3-4. スタッフ構成}

自然学校のスタッフは 2007 年時点で金沢大学教員 2 名のほか、 非常勤職員として地域連携コーディネーター 2 名、研究員 2 名、事 務員 2 名で構成されている(図 5 )。

非常勤職員らは、2002 年度に前述の「地域貢献特別支援事業」 に採択されたことにより採用が始まっている。また、2005 年度の 特別教育研究経費により、全国の大学、県内自治体、民間団体及 び地域住民等とのパイプ役を担う専任の地域連携コーディネーター (客員教授）2名が採用されている。コーディネーターは大学と多 
表 3 主な活動主体と活動概要

\begin{tabular}{|c|c|c|c|c|c|c|c|c|c|c|c|c|c|c|}
\hline & \multirow{2}{*}{\multicolumn{2}{|c|}{ 活動団体及び活動名 }} & \multicolumn{5}{|c|}{ 主な活動内容 } & \multicolumn{4}{|c|}{ 活動頻度 } & \multirow[b]{2}{*}{$\begin{array}{l}\text { 開始 } \\
\text { 年度 }\end{array}$} & \multirow[b]{2}{*}{ 活動場所 } & \multirow[b]{2}{*}{ 支援・協力団体 } \\
\hline & & & 堡 & \begin{tabular}{|l|} 
体験 \\
\end{tabular} & \begin{tabular}{|l|} 
掣 \\
\end{tabular} & \begin{tabular}{|l|} 
喾 \\
\end{tabular} & \begin{tabular}{|l|} 
研 \\
究 \\
\end{tabular} & \begin{tabular}{|l|l|} 
䝓 \\
\end{tabular} & & & 孁 & & & \\
\hline \multirow{6}{*}{$\begin{array}{l}\text { 黒 } \\
\text { 山 }\end{array}$} & & 田復元グループ（A） & - & - & & & & 0 & & & & 2002 & \multirow{10}{*}{ 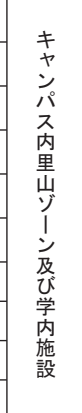 } & \\
\hline & & ナラグループ (B) & $\bullet$ & & & & - & & 0 & & & 2003 & & \\
\hline & & し子くらぶ(C) & - & - & & & & 0 & & & & 2003 & & 白然学校 \\
\hline & & 杂めグループ (D) & & - & - & & & & 0 & o & & 2004 & & \\
\hline & & 間の里農園グループ (E) & & - & & & & & 0 & & & 2005 & & \\
\hline & & 孛き・雑木林整備グループ (F) & - & & - & & & & & & 0 & 2007 & & \\
\hline \multirow{7}{*}{ 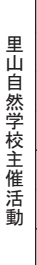 } & & 活動 & - & - & - & & & & $\circ$ & & & 1999 & & 里山メイト \\
\hline & & テッチクラブ & & & - & & & & 0 & & & 2006 & & 金沢大学 \\
\hline & & 勿調查 & & & & & - & & & & 0 & 1999 & & 金沢大学 \\
\hline & 講翌 & 罡会 & & & & - & & & & & o & 2001 & & 他団体など \\
\hline & & 山里海自然学校 & - & - & $\bullet$ & & & & $\circ$ & & & 2006 & 能登半島 & 特になし \\
\hline & & 山里海リーダー養成講座 & & & & $\bullet$ & & & & & 0 & 2007 & \multirow{11}{*}{ 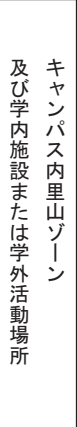 } & 里山メイト \\
\hline & & 登里山マイスター」養成講座 & & & & - & & & 0 & & & 2007 & & 特になし \\
\hline \multirow{9}{*}{$\begin{array}{l}\text { 里 } \\
\text { 山 } \\
1 \\
⺊ \\
\vdots \\
\text { 里 } \\
\text { 自 } \\
\text { 然 } \\
\text { 学 } \\
\text { 椄 } \\
\text { 活 } \\
\text { 動 }\end{array}$} & & 凤子ども科学財団（K 財団） & & - & & & & & & o & & 2002 & & \multirow{6}{*}{$\begin{array}{l}\text { 里山メイト } \\
\text { 自然学校 } \\
\text { (学生) }\end{array}$} \\
\hline & & 上小学校 (T 小学校) & & & & - & & & ० & & & 1999 & & \\
\hline & & 里小学校 (M 小学校) & & & & - & & & & o & & 2007 & & \\
\hline & & 一小学校（K小学校） & & - & & & & & & & 0 & 2005 & & \\
\hline & & 学部附属校，小・中学部 & & - & & & & & & & 0 & 2000 & & \\
\hline & & 学部附属養護学校（附属校 Y) & & & - & & & & & 0 & 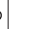 & 2001 & & \\
\hline & & ビ金沢 & & - & & & & & & & o & 2007 & & \multirow{3}{*}{ 自然学校 } \\
\hline & \multirow{2}{*}{\begin{tabular}{|l} 
震 \\
霖
\end{tabular}} & 佛子園 & & - & & & & & & & 0 & 2007 & & \\
\hline & & 金沢南ロータリークラブ & - & & & & & & & & o & 2007 & & \\
\hline
\end{tabular}

様な地域との交流・連携調整を担っている。

\section{3-5. 活動の拠点施設}

自然学校の活動は、発足当初は拠点施設がなく、駐車場等を集合 場所として屋外活動を行ってきた。そのため、雨天時などは活動を 中止せざるをえないなど天候による影響を大きく受けていた。屋内 活動に関しては、大学の教育開放センター等を利用し実施されてきた。

しかし、2005 年からは、金沢大学創立 50 周年記念事業の 1 つと して卒業生らの寄付によって創設された記念館「角間の里」を活動 拠点としている。この施設には、多目的に使える土間や 1 階多目的 空間、2 階展示スペース、前庭などがあり、自然学校の活動時には 屋内活動や会合、休喤スペースとして使用される他に、活動日以外 にも地域住民らの交流の場としても使用されている。また、自然学 校の事務局もその拠点施設内にあり、スタッフが常駐している。

\section{3-6. その他の取り組み}

自然学校では、2005 年 12 月から、「里山駐村研究員制度」（以下 研究員制度）という新しい活動を開始している。この研究員制度で は、大学の研究に民間の力を加える「民学連携」の新しい試みとし て、里山保全や地域の活性化等に取り組んでいる人を「里山駐村研 究員」や「里山客員研究員・客員調査員」として委嘱している。研 究員らは、地域の里山活動に関する情報提供や大学一の提言、研究 者との意見交換など、大学と連携した活動などを行っている注7)。

また、学外一向けた取り組みの 1 つとして自然学校での活動の経 験を活かして、2006 年 10 月に「能登半島里山里海自然学校」（以 下里山里海自然学校）を設立している注8)。里山里海自然学校は、 奥能登で活躍する人材と協力しながら、身近な自然である里山や里 海の保全と再生、環境に配慮した農林水産業を基盤とした地域振興 策の提言を行うことを目的としている。

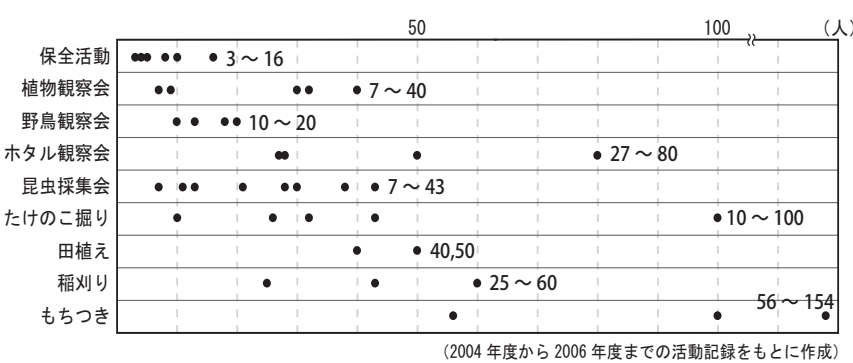

図 6 定期活動の主な活動別の参加者数

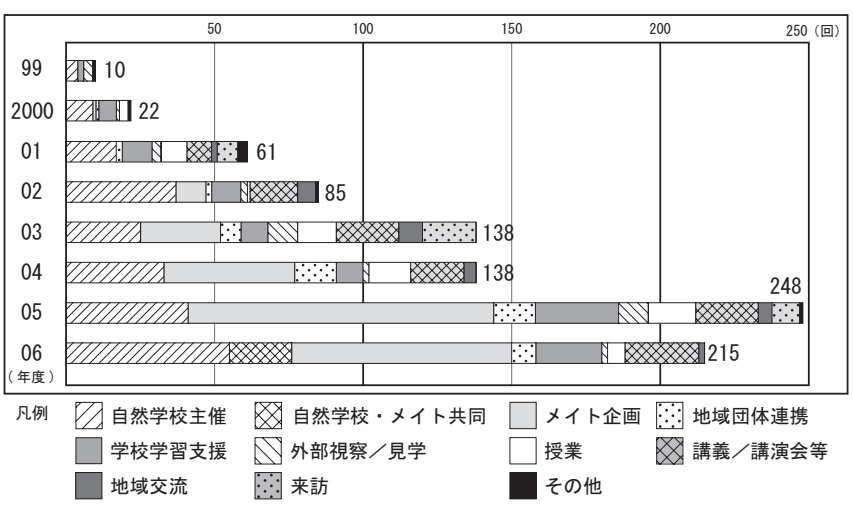

図 7 年度ごとの全体活動開催数にみる主催・内容別活動の割合

\section{4. 自然学校の活動の実態把握と分析 \\ 4-1. 自然学校の活動内容}

現在は、まず定期活動である保全活動や自然観察会、田んぼ作業 などのほかに、植生調查やスケッチクラブ、講習会などが自然学校 主催の活動として行われている。また自然学校が協力・支援を行う 連携活動として里山メイトの企画活動や小学校や財団など地域団体 との活動がある（表 3 )。自然学校主催の活動や地域団体の活動で は体験・学習型の活動が多いのに対して、里山メイトの活動では保 全活動を主体とした活動が多い。自然学校主催による定期活動の主 な内容及びその参加者数を図 6 に示す。数名から 100 名超まで、活 動の内容により参加者数の幅は見られるが、図 6 に示寸全 40 回の 活動のうち 10 ～ 60 名の参加があった活動が 30 回（75\%）を占め ることから、比較的多くの参加者を集めていると考えられる。

\section{4-2. 発足時からの活動の変遷}

年度ごとの活動全体について、主催・内容別に分類し、整理した (図 7 )。活動によっては複数日に渡って行われているものがある が、その場合は、まとめて 1 活動と数えている。

活動は年度ごとに活発になっていく様子がみて取れる。特に着目 すべき点として、里山メイト企画の活動がある。里山メイトが発足 した 2002 年度から、里山メイトが企画した活動が実施されるよう になったが、年を重衫るごとに拡大しており、近年では里山メイト の活動が全体の活動数の半数近くを占めている。さらに地域団体の 活動には里山メイトが協力していることから、里山メイトの存在が 自然学校の活動基盤をつくっているといえる。また、2002 年度か ら自然学校は非常勤職員の採用を行なっており、里山メイトの存在 だけでなく、自然学校の業務を支える基盤ができたことも活動数の 増加の要因のひとつといえる。

\section{4-3. 活動の課題点}

発足以来、参加者の増加によって定期的に活動が行われるように 
表 4 里山メイトグループの概要

\begin{tabular}{|c|c|c|c|c|c|c|c|c|}
\hline グループ名 & \begin{tabular}{|l|} 
\\
助成 \\
素
\end{tabular} & 用途 & 活動内容 & 人数 & $\begin{array}{l}\text { 結成の } \\
\text { きっかけ }\end{array}$ & 問題点など & \begin{tabular}{|l} 
助成金 \\
取得時期
\end{tabular} & $\begin{array}{l}\text { 焣得の } \\
\text { きっかけ }\end{array}$ \\
\hline $\begin{array}{c}\text { 藍染め } \\
\text { ブループ } \\
\text { (グループD) }\end{array}$ & \multirow{4}{*}{ ) } & \multirow{2}{*}{$\begin{array}{l}\text { 体 } \\
\text { 学 } \\
\text { 習 }\end{array}$} & \begin{tabular}{|l|} 
藍の種植え \\
での染色ま程 \\
を実践・研 \\
究している。
\end{tabular} & 10 名 & 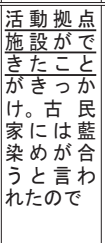 & 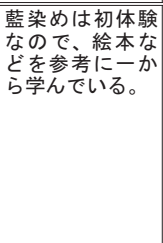 & 06 年度 & 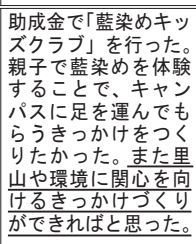 \\
\hline $\begin{array}{c}\text { 角間の里 } \\
\text { 農園 } \\
\text { グルプ } \\
\text { (グループE) } \\
\end{array}$ & & & $\begin{array}{l}\text { 野菜づくり } \\
\text { 米づくり } \\
\text { を } 1 \text { 年をか } \\
\text { けて行い、 } \\
\text { 栽培、収穫、 } \\
\text { 加エまでを } \\
\text { 参加者に体 } \\
\text { 験させてい } \\
\text { る。 }\end{array}$ & 2 名 & $\begin{array}{l}\text { 活動拠点 } \\
\text { 施設の完 } \\
\text { 成ととも } \\
\text { に前庭に } \\
\text { 畑ができ } \\
\text { たため }\end{array}$ & 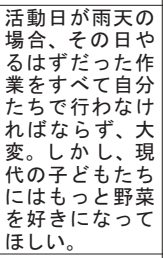 & 05 年度 & 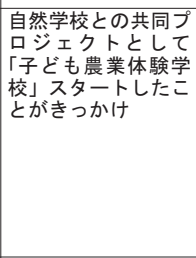 \\
\hline $\begin{array}{c}\text { コナラ } \\
\text { グループ } \\
(\text { グループ B) }\end{array}$ & & \multirow{2}{*}{ 保 } & $\begin{array}{l}\text { 柞林の再生 } \\
\text { 遊歩道の整備 }\end{array}$ & 5 名 & 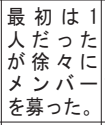 & $\begin{array}{l}\text { やる気のある人や } \\
\text { 問題意識の高い人 } \\
\text { がなかなか集まら } \\
\text { ず、人手不足。 }\end{array}$ & $\begin{array}{c}05 \sim 06 \\
\text { 年度 }\end{array}$ & $\begin{array}{l}\text { 植生調査費として。 } \\
\text { 植生調査が里山保全 } \\
\text { では必要不可疮なた } \\
\text { め }\end{array}$ \\
\hline $\begin{array}{c}\text { 竹ん子 } \\
<ら ら ふ ゚ ~ \\
\text { (グループC) }\end{array}$ & & & 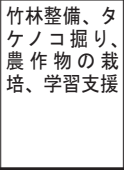 & 16 名 & 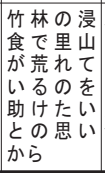 & $\begin{array}{l}\text { 助成金取得にあ } \\
\text { たつて,自己資金 } \\
\text { を確保しなけれ } \\
\text { ならず、作物 を } \\
\text { 売ったり、個人資 } \\
\text { 金により調達し } \\
\text { た。 }\end{array}$ & 05 年度 & $\begin{array}{l}\text { 竹林の整備には多く } \\
\text { の人の助げ必要な } \\
\text { のと同時に作業を進 } \\
\text { めるには資金も多く } \\
\text { 必要なため }\end{array}$ \\
\hline $\begin{array}{l}\text { 棚田復元 } \\
\text { グループ } \\
(\text { グループA) } \\
\end{array}$ & \multirow[t]{2}{*}{$\begin{array}{l}\text { t } \\
5 \\
2 \\
\tau \\
\cdots \\
\text { な } \\
1\end{array}$} & & $\begin{array}{l}\text { 棚田の復元、 } \\
50 \text { 年前の田 } \\
\text { に ぼ作 業体 } \\
\text { 験、学習支援、 } \\
\text { 水生動植物の } \\
\text { 再生 (ホタル } \\
\text { など) }\end{array}$ & 10 名 & \begin{tabular}{|l|} 
荒廃して \\
した棚田 \\
を復元し \\
たいと自 \\
然学校か \\
らの要望 \\
があったた \\
ため \\
ため
\end{tabular} & $\begin{array}{l}\text { 棚田の復元は収穫 } \\
\text { 的ではなく、研 } \\
\text { 究のフィールドづ } \\
\text { くりや農業体験の } \\
\text { ためなので、基本 } \\
\text { 的に農藥等を使用 } \\
\text { できず、手入れが } \\
\text { 大変。田んぼ作業 } \\
\text { は家庭や地域で異 } \\
\text { なるため、意見の } \\
\text { 衝突もしばしば。 }\end{array}$ & & \\
\hline $\begin{array}{c}\text { 宸焼き } \\
\text { グループ } \\
\text { (グループF) }\end{array}$ & & & $\begin{array}{l}\text { 炭焼き小屋 } \\
\text { の製 作、雑 } \\
\text { 木林の整備 }\end{array}$ & 5 名 & \begin{tabular}{|l|} 
学生サー \\
クルがで \\
きたこと
\end{tabular} & $\begin{array}{l}\text { 学生が主体である } \\
\text { ため、活動がどう } \\
\text { しても不定期に } \\
\text { なってしまう。 }\end{array}$ & & \\
\hline
\end{tabular}

なったことで、活動が定着し、自然学校の活動が発展してきたとい える。さらに里山メイトの発足により、それまで参加者であった地 域住民らが自ら企画を提案・実施するなど、自然学校の活動は次第 に地域住民が主体となった活動へと変化している。

また、参加者の多くは地域住民であり、キャンパス内に拠点を構 える活動であるが、学生や教員など大学関係者の参加は少ない。金 沢大学では学部生に対して、自然学校の活動に合流参加できる体験 型の授業科目注9) を開講しているが、授業をきっかけに自然学校の 活動に参加する学生もあまりみられないのが現状である。

\section{5. 自然学校と里山メイトとの連携活動}

\section{5-1. 里山メイトによる連携活動の現状把握}

2003 年度からは、自然学校との連携活動として、里山メイトが 企画した活動が実施されるようになっているが、現在、自然学校 との連携活動を実施している活動グループは 6 グループである（表 4)。ここでいう活動グループとは、里山メイトの会員であり、自然 学校の活動にも参加しているが、それとは別に、同じ活動目的・問 題意識を持った者同士が集まり、キャンパス内のフィールドを活用 し、積極的に独立した活動を行うグループをいう。メンバーは自然 学校の発足当初から参加している者が多く、自然学校の発展に合 わせて、グループ活動を開始していることがわかる。活動資金は里 山メイトの会費から 6 グループに対して均等配分されるため、グ ループによっては必要に応じて助成金を取得しており（グループ

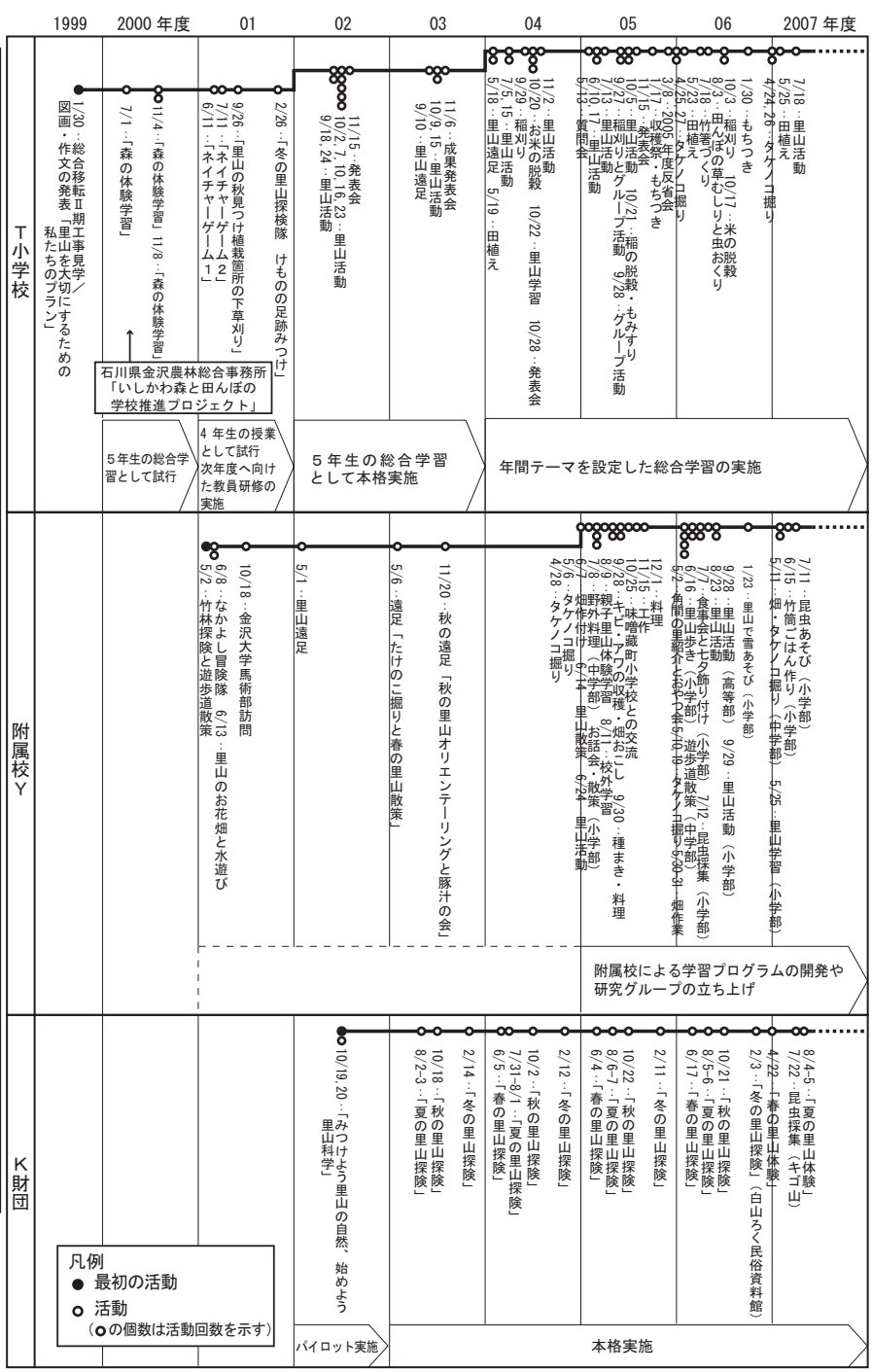

図 8 地域団体と自然学校の定期的な連携活動の変遷

B/C/D/E)、主体的な活動へと進展していることがうかがえる。しか し一方では、各グループの活動内容と会費から均等に配分される活 動資金のバランスが必ずしもとれているわけではないため、資金面 で問題を抱えているグループもある。

\section{5-2. 里山メイトからみた自然学校の評価}

ヒアリングから、地域住民や団体との交流が持てる点や大学の研 究・教育活動に関われる点を評価しており、自然学校が各々をつな ぐ中間的役割を果たしていることがわかる。また拠点施設の完成に より、雨天時の心配がなくなった点や、日常的な情報交換の場になっ ている点、常駐スタッフに相談ができる点など、活動が大きく変化 したことを挙げている。

\section{5-3. 里山メイトと自然学校との連携に関する課題}

自然学校の支援により、活動機会を得た里山メイトらはグループ 活動を通して参加者としてだけではなく、自然学校の活動自体を支 援する役割も担うようになっていることは成果の 1 つといえる。

しかし、特化した活動をする里山メイトがいる一方で、自然学校 の活動や拠点施設が一部の参加者による活動や交流の場になってい ることや、新規の参加者が少ないとの指摘もあった。さらに、キャ ンパス緑地に関する大学運営のビジョンが不明確なために、保全活 
地域団体と自然学校の連携活動の概要

\begin{tabular}{|c|c|c|c|c|c|c|}
\hline 団体名 & 連携のきっかけ & 連携の目的 & 他の活動における連携活動の位置づけ & 活動内容の計画 & 今後のビジョン・要望 & 連携活動の評価 \\
\hline $\begin{array}{c}\mathrm{K} \\
\text { 財 } \\
\text { 団 }\end{array}$ & $\begin{array}{l}\text { 財団設立時の事務局長が元金沢 } \\
\text { 大学理学部教員で、同じ理学部 } \\
\text { 教員の自然学校代表に連携を持 } \\
\text { ちかけた。 }\end{array}$ & $\begin{array}{l}\text { 現代の子どもたちに身 } \\
\text { 近な環境で自然と触れ } \\
\text { 合わせることで、色々 } \\
\text { なものに興味を示して } \\
\text { ほしいと思ったから。 }\end{array}$ & $\begin{array}{l}\text { 数ある活動の中でも、年間を通して行ってい } \\
\text { る活動は少ないので、全活動の中でも中心的 } \\
\text { な活動になっており、また子どもたちに人気 } \\
\text { のある活動のひとつである。 }\end{array}$ & $\begin{array}{l}\text { 活動内容については, } \\
\text { 全面的に自然学校に } \\
\text { 計画を立ててもらっ } \\
\text { ている。財団では、 } \\
\text { 参加者の募集のみ } \\
\text { 行っている。 }\end{array}$ & $\begin{array}{l}\text { 角間キャンパス内に留ま } \\
\text { らず、能登にできた里山 } \\
\text { 里海学校へと活動を広げ } \\
\text { ていきたい。 }\end{array}$ & $\begin{array}{l}\text { 学生らと子どもたちがコ } \\
\text { ミュニケーションをとれる } \\
\text { ことが良い。また、自然学 } \\
\text { 校のスタッフや里山メイト } \\
\text { がサポートしてれること } \\
\text { や、大学が管理している } \\
\text { フィールドを使用できるこ } \\
\text { とで、安心感がある。 }\end{array}$ \\
\hline $\begin{array}{l}\text { 附 } \\
\text { 属 } \\
\text { 校 } \\
\text { Y }\end{array}$ & $\begin{array}{l}\text { 教育学部附属なので、附属校教 } \\
\text { 員と教育学部教員の自然学校事 } \\
\text { 務局長との交流があり、自然学 } \\
\text { 校の存在を知った。附属校に自 } \\
\text { 然が好きな教員がたく忘いた } \\
\text { ことや大学内なので安があ } \\
\text { ることがきっかけで活動を開始 } \\
\text { るた。 }\end{array}$ & $\begin{array}{l}\text { 机上での学習ではな } \\
\text { く、外へ出て、本物の } \\
\text { 自然に出うこ会うを経験をし } \\
\text { して、色を } \\
\text { てもらいたいと思った } \\
\text { から。 }\end{array}$ & 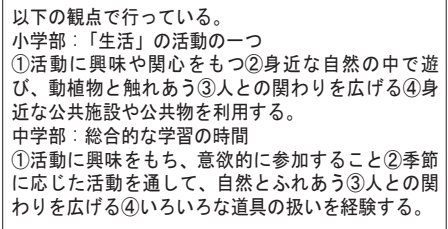 & 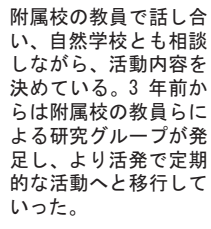 & 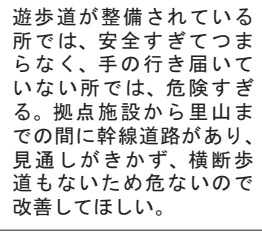 & $\begin{array}{l}\text { 管理された(されてない部 } \\
\text { 分も多いが)里山なので、 } \\
\text { 安心して活動ができる。 } \\
\text { 色々なことを自由にやらせ } \\
\text { てもらえる需囲気がある。 } \\
\text { 拠点施設には里山メイトや } \\
\text { 研究員がいつもいるので子 } \\
\text { どもとの交流が生まれるこ } \\
\text { とが良い。 }\end{array}$ \\
\hline $\begin{array}{l}T \\
\text { 小 } \\
\text { 学 } \\
\text { 校 }\end{array}$ & $\begin{array}{l}\text { キャンパスが校区内ということ } \\
\text { もあり、エ事現場の見学をきっ } \\
\text { かけに連携がスタート。当時の } \\
\text { 校長や教頭が環境教育にに熱心で } \\
\text { あったことともあ、継続した関 } \\
\text { 係が続いている。 }\end{array}$ & $\begin{array}{l}\text { 校区内の自然に関心を持 } \\
\text { ち、自然について自た } \\
\text { ちの課題を持って調べる } \\
\text { 態度を育てる。地域への } \\
\text { 関わり方も学ぶ。 }\end{array}$ & $\begin{array}{l}2002 \text { 年からは } 5 \text { 年生の総合的な学習の時間に } \\
\text { 組み込まれている。 }\end{array}$ & （記述なし） & （記述なし） & （記述なし） \\
\hline
\end{tabular}

\begin{tabular}{|l|l|l|l|l|}
\hline 実 & $\begin{array}{l}\text { 金沢大学のキャンパスや教員との } \\
\text { 接点が見られる } \\
\text { 緑地を活用した活動に関心がある }\end{array}$ & 総合的な学習の時間や 1 事業としての位置づけがなされている & 関係の継続を期待している \\
\hline $\begin{array}{l}\text { されたパス内の管理 } \\
\text { さ地域との緑地) に対する評価 } \\
\text { 流を評価 }\end{array}$
\end{tabular}

動が行いにくいという指摘があった。

\section{6. 自然学校と地域団体との連携活動}

\section{6-1. 地域団体との連携活動の全体把握}

自然学校は発足当時からキャンパス周辺の地域団体との連携活動 も行なっている（表３）。連携活動を行なっている団体は、キャン パスを校区に含む小学校や大学の附属校、財団、児童館、市民団体 などである。地元小学校や附属校、財団とは年間を通して定期的な 連携活動を行なっている。活動には自然学校がサポートするほか、 里山メイトが企画にあわせて技術的なサポート等を行なっている。

\section{6-2. 地域団体との定期的な連携活動の内容}

定期的な活動を行っている団体は、T小学校、附属校 $\mathrm{Y} 、 \mathrm{~K}$ 財団 の 3 団体である（図 8 )。

T小学校は、自然学校発足当初から連携活動を行っており、2002 年度からは 5 年生の総合学習の時間に位置づけている。また、里山 メイトから活動の技術的サポートを受けているほか、活動場所の借 り入れを里山メイトが仲介するなど、自然学校と里山メイトの両者 が活動を支援している。附属校Yは、2001 年度から連携活動を行っ ており、2005 年度からは研究グループを立ち上げ、連携活動にお ける学習プログラムを研究している。K財団は、金沢大学との連携 活動を多く行っており、その一つに自然学校との連携活動があり、 毎年 4 回ほど実施している。

活動内容は、K財団は全面的に自然学校に任せているのに対し て、T小学校と附属校Yでは、教員らが独自にプログラムを組み、 自然学校と調整して活動内容を決定している。また、これらの連携 活動には里山メイトや学生も協力している。

連携活動を継続する中で、連携活動回数の増加、里山メイトや自 然学校の単発的な参画から年間プログラムへの参画への移行、学習 プログラム開発への参画などが行われており、地域団体側における 自然学校の位置づけの重要度は増していると考えられる。

\section{6-3. 地域団体からみた連携活動の評価}

定期的に連携活動を行っている 3 団体の自然学校に対する評価を
ヒアリングや成果報告書から把握した（表 5)。連携活動を始める きっかけは、校区がキャンパスに隣接していることや以前から自然 学校関係者と知り合いであったことが挙げられている。連携活動に 対しては、3 団体とも、大学の管理されたフィールドで活動できる ことが安心感につながっており、学生や里山メイトなど普段接点の ない人たちとのコミュニケーションや環境教育の場として連携活動 の意義を指摘している。

\section{6-4. 地域団体と自然学校の連携に関する課題}

定期的な連携活動を行っている団体は、現在のところ大学関連や 地元の小学校に限られるため、体験や学習活動が中心であるが、総 合的な学習の時間や財団の 1 事業としての位置づけが明確になされ ている。その理由は、小学校や財団にとって、身近な自然環境をテー マにした学習を可能とする安全な学習フィールドや、支援する専門 家や協力者を安定して確保できるためである。これらの点に両者は 自然学校との連携の意義を見出している。しかし、この連携活動は 現在の体制では自然学校のスタッフへの負担が大きく、今後の地域 団体の連携活動の増加には、対応しづらい状況にあると思われる。

\section{7. 自然学校と地域住民・団体との関係の変化の考察}

これまでの分析をふまえて、自然学校発足から現在までの組織変 遷、地域住民・団体との相互関係をまとめた（図 9)。そして地域 との連携による自然学校の活動実態と連携体制の進展過程を整理 し、その要因を考察する（図 10）。

\section{7-1. 活動前段階にみる関係の特徵}

創立 50 周年記念事業やキャンパスの第 II 期工事などが進む中で、 教員によるキャンパスの自然を活か寸方法の提案が発端となって、 キャンパス整備や活用を目的に「角間の里山自然学校」が発足する。 構想段階において、地元の土地区画整理組合へ協力を依頼したこと が地域と大学の最初の接点であり、その後、大学関係者と地元住民 を交えた里山の現状把握、意見交換会を開いている。自然学校の発 足前後から大学側が協力依頼することで、地域住民とネットワーク を構築し、活動の支援体制を整えていることがうかがえる。 


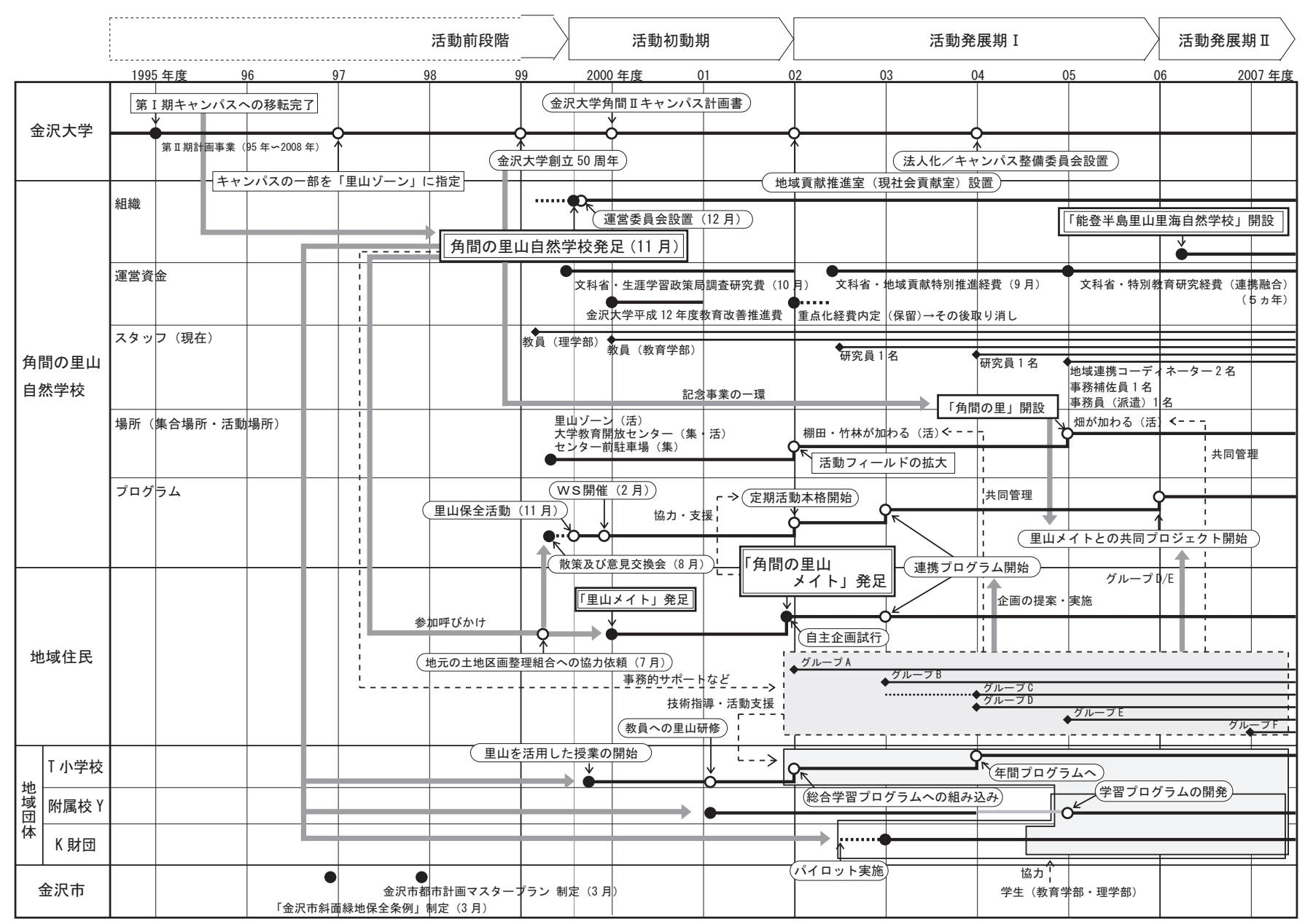

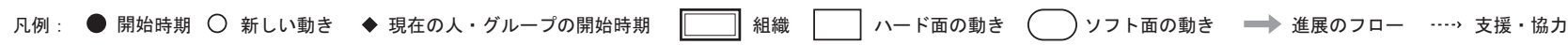

図 9 自然学校の組織変遷と地域住民・団体との相互関係

\section{7-2. 活動初動期にみる関係の特徵}

自然学校発足後の初動期では、大学の呼びかけにより集まった地 域住民は「参加者」として活動に関わっていた。活動参加者は一部 の地域住民や大学関係者に限られていたが、積極的に保全活動に参 加したり、他の参加者に指導する者の姿が見られるようになってき ている。自然学校も地域住民との交流の場としてワークショップを 開催し、意見や要望を引き出している。

\section{7-3. 活動発展期 I にみる関係の特徵}

不定期であった活動が日時を固定した定期活動へと移行してい る。同時に活動により積極的に関わりたいと考える一部の住民らが 「角間の里山メイト」を立ち上げている。この里山メイトの発足に より、新しい活動企画が次々と実施されるようになり、自然学校の 活動の幅が拡大したほか、棚田や竹林などの新しい活動フィールド が加わった。また、運営面において、文部科学省の「特別支援事業」 に採択されたことにより、非常勤職員の採用が可能となり、自然学校 の活動に関する事務的処理等がスムーズに行われるようになっている。 里山メイトの発足によるグループ活動の開始、活動の定期化、非常勤 職員の採用など、自然学校の活動体制が整ってきた時期だといえる。

\section{7-4. 活動発展期 II にみる関係の特徵}

活動発展期 I では里山メイトは自身の企画活動を自主的に行って きたほか、自然学校の活動に対しては技術面でのサポートを行って きたが、この時期になると、個別に活動を計っていた自然学校と里

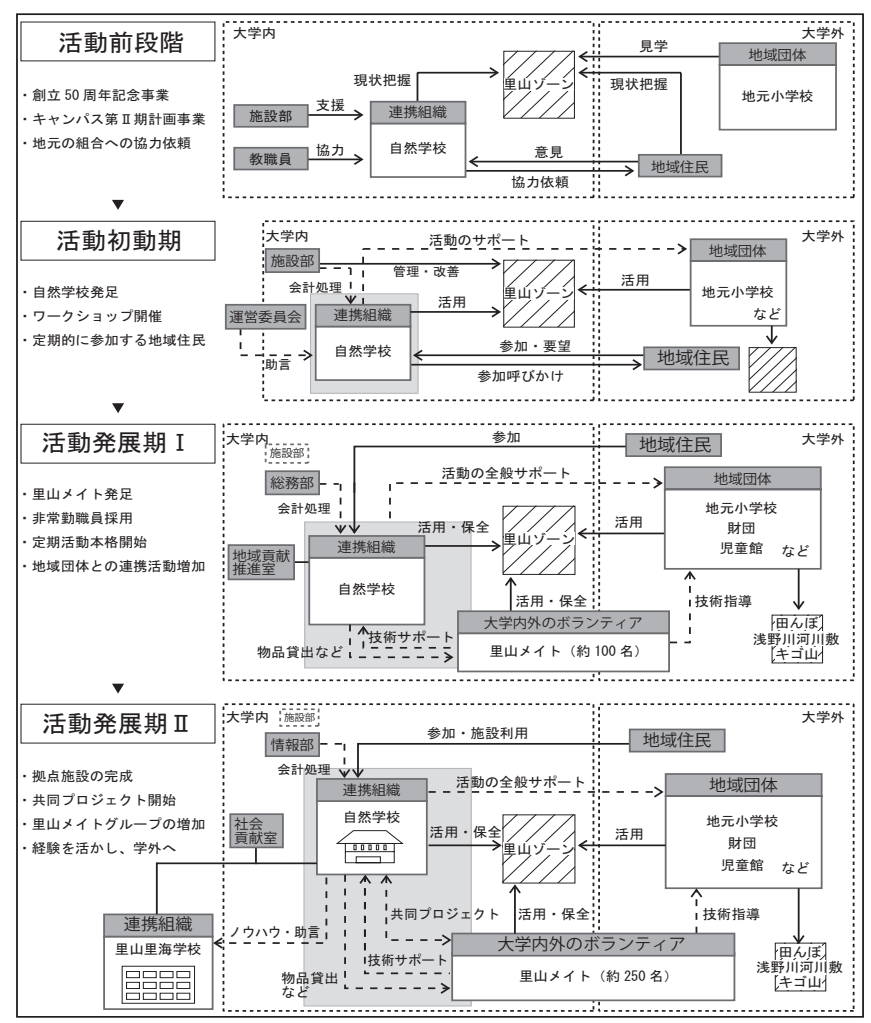

凡例 $\square$ 緑地 $\square$ 組織 $\square$ 企画主体 $\longrightarrow$ 活動 $--\rightarrow$ 支援・協力 - 組織的な関係 図 10 活動段階別の自然学校を取り巻く関係図 
山メイトの両者による共同プロジェクトが始まっている。共同プロ ジェクトでは、自然学校の活動の 1 つを里山メイトが主導して、企 画から運営までを担っている。この共同プロジェクトが実施される ようになったきっかけのひとつに拠点施設の完成がある。拠点施設 の完成により、自然学校の専任スタッフが常駐し、活動日以外にも 地域の交流の場としても使用されている。

\section{7-5. 段階的進展を促す要因}

このように、活動や連携体制が段階的に進展していることが理解 できたが、それを促す要因としては次の点が考えられる。

(1)活動を主導し支援する専門家、空口となって安定した運営を支援 するスタッフ、固定した活動拠点を漸次的に整備している。

(2)参加者の関心を基本にしながら、徐々に活動を定期化し拡張して いる。

(3)里山メイトや地域団体といった活動への理解者や協力者の取り込 みと、その自主的な組織化、そして自然学校との対等な関係に よって活動を実施している。

\section{8. 総括}

大学キャンパスは都市や地域において比較的規模の大きな敷地で あり、その中にまとまった緑地を有するキャンパスも少なくない。 よって、温暖化低減、生態系保護等の課題克服や低炭素型都市の実 現に対して都市・地域レベルでの取り組みが今後強く求められる中 で、キャンパスの緑地が存在する意義や役割は今後その重要度が高 まるものと思われる。つまり、キャンパス内のまとまった緑地をい かに計画し、マネジメントしていくかは、大学だけでなく、都市・ 地域にとっても今後重要な課題となってくると考えられる。この ような観点から本研究で考察した自然学校とその活動を見直せば、 キャンパス緑地を地域の公共空間、地域資源と見なし、それを地域 と大学が協働してマネジメントすることを志向した我が国における 先進的な組織であり、取り組みの積み重ねであると言える。

そこで、これまでの分析をふまえて、自然学校の成果や到達点か ら学び得る知見を整理するとともに、広く地域と大学の連携組織に 関する考察を行いたい。

\section{8-1. 地域資源としての大学を活かす協働活動拠点}

大学の発意で発足した自然学校が主催する活動の多くが、キャン パスの緑地を題材やテーマにしながらも、視野を広げ、研究者を招 いた勉強会や研究活動への参加といった体験・学習型活動であった ことは、スタッフの専門性もあるが、教育研究機関ゆえの特色でも ある。一方、地域住民によって構成される里山メイト主催の場合は、 より保全活動に重心が置かれている点は、里山としてのキャンパス 緑地に対する地域住民の関心を示しているといえる。2つの志向性 を併せ持ちながらも、自然学校は大学の知的、人的資源と空間資源 をマッチさせ、緑地であり里山である空間を題材にした活動を卯化 させる拠点組織となっている。さらに、大学が所有、管理する空間 を地域資源とみなし、大学と地域双方の人材や知的資源、活動プロ グラムを組み入れながら、段階的に進展している。現段階での活動 範囲はキャンパス緑地の一部に留まるが、そのノウハウは他地域(能 登半島）での連携事業等へも活かされており、大学発地域連携組織 の進展と成果として一定の評価ができよう。

\section{8-2. 市民ベースの活動や担い手を育てる役割}

保全・活用の活動を重ねる中で、自然学校の活動を支援するた めの市民組織（里山メイト）がうまれたことにより、自然学校と地 域住民との間に実質的な協働関係が構築されていった。キャンパス の緑地であり、近隣住民にとっては里山であるキャンパス緑地の保 全・活用は、地域住民や市民が関心を持ちやすく、参加しやすい活 動であり、それが市民主導の活動組織が発足するにまで至った要因 として考えられる。同時に、リーダー的住民の存在も無視できない。 さらに現在では、市民が主体となってキャンパス緑地の保全や活用 に向けた活動を展開するケースが出てきており、自然学校が前項で 述べた学内の人材や知識、空間を学外の動きとつなぐ役割だけでな く、市民ベースの里山保全活動自体や次の担い手を育てる場として も機能している。地域と大学の連携組織が果たすべき重要な役割と して指摘できる。

\section{8-3. 連携空ロとしての役割}

地域と大学の連携活動が段階的な成果を得るためには、専任ス タッフの存在や専用の拠点施設の存在も安定的な活動を支える重要 な要因となっている。特に常設の拠点施設ができ、自然学校ならび に大学と地域住民との接点となる日常的な場が設けられたことは、 その関係を深める大きな要因となっている。TLO など大学の知的財 産を地域と共有するための連携組織は各大学に存在するようになっ て久しいが、都市・地域空間としてキャンパスを協㗢でマネジメン 卜寸るという視点からは、地域と大学の双方の空口の不在や不明確 さは度々指摘されている。双方にとって目に見える空口組織の存在 の重要性を改めて指摘できる。

\section{8-4. 大学の長期ビジョンにおける連携組織の位置づけ}

キャンパス開発に伴って荒れた緑地の回復を目的にして設立され たという点に自然学校の先進性があり、これまでに協働による活動 の基盤や連携関係は構築されたといえる。しかし現在では大学の キャンパスに関するビジョンが見えにくいために、自然学校での保 全活動が難しいという指摘が里山メイトからされている点には注意 が必要である。我が国において地域連携によるキャンパスの計画や マネジメントは途についたところであり、自然学校のみならず、地 域連携による活動や事業、連携組織や体制づくりをキャンパスの計 画・マネジメントや大学の長期ビジョンにいかに位置づけて実施す るのかについては、これからの共通課題である。

\section{8-5. 連携組織の経営に関する課題}

さらに、自然学校は財政的には主に文部科学省の助成金によって 運営されており、今後の財政的な継続性の点では課題が残る。大学 の地域連携組織の財政の課題に関して、米国の大学ベース型コミュ ニティ・デザイン・センターでは、民間財団など地域からの寄付金 などによって運営資金が確保され、それを元に地域との連携プロ ジェクトが実施される社会的構造が、財政的な継続性や安定性を生 み出している ${ }^{8)}$ 。しかし、我が国において同様な条件がこれから短 期間で整備されることは期待しにくいのが現状であり、自然学校の ような地域連携組織を大学運営上、特に財務上どのように位置づけ るのかは課題である。財務の問題は、わが国における地域と大学の 連携事業において共通した検討課題として、存在している。

付記本研究は日本学術振興会科学研究費補助金（課題番号 19560614、21560635 代表：小松尚）の一環で行われた。 
注1）地域住民とは里山メイトを指し、その中で里山メイトの活動グループのリー ダーら 8 名を対象に 2007 年 12 月にヒアリング調査を行った。対象者の中には 里山メイトの代表や里山メイト幹事、元土地所有者、他の環境団体で活動して いる者らがいる。地域団体については定期的な連携活動を行っている 3 団体の うち、K 財団と附属校 $Y$ ヘヒアリングを行った。 $K$ 財団へは連携活動時に指導 を担当している財団の指導ディレクターへ、附属校 $Y$ へは連携活動の企画や研 究を主導的に行っている教員 2 名にそれぞれヒアリングを行った。T小学校は、 連携当初を知る教員が残っていないため、ヒアリングを行えなかったが、自然 学校関係者へのヒアリングや成果報告書から実態を把握した。

注2） 1997 年度に大学として里山ゾーン（自然園 12ha と環境保全自然研究林 62ha) を指定している。この里山ゾーンは、公式的には 2000 年度にまとめられた「金 沢大学角間 IIキャンパス計画書」にはじめて明記された。なお、角間キャンパ スの一部は 1997 年 3 月に『金沢市斜面緑地保全条例』において風致地区（第 1 種）に指定されているが、自然学校の関係者へのヒアリングによると、風致地 区指定と里山ゾーン指定には直接的な関係はなかったという。

注3）主な組織として熊本大学工学部の「まちなか工房」や関東学院大学の「追浜こ みゆに亭」等がある。「まちなか工房」は、2005 年から文科省の助成を受け、市 域中心部の上通並木坂商店街にある店舗ビルのワンフロアを借りて開設された。 都市計画分野の専門知識や技術の提供、学習会やWSによる官民の交流機会の 提供、中心市街地活性化に向けた組織連携の推進役などの役割を担っている。 「追浜こみゅに亭」は、2004 年に大学の演習や研究室の学生の地元研究の拠点、 地元住民の独自企画の研究会やまちづくり会合に利用できる。以上の事例に代 表されるように、大学が空洞化する地域の中心市街地に拠点を構えて、地域主 体と協働して課題解決とフィールドでの教育研究を目的に実践的な活動が展開 されている。

注4) 運営委員会は、金沢大学の教員 (文学部、法学部、経済学部、理学部、薬学部) や石川県の職員、地元住民らで構成され、学長が名誉顧問、副学長が顧問を務 める。

注5）里山メイトの主な登録者は、元土地所有者を含む地元住民や大学関係者、他の 環境団体や環境活動への参加者である。

注6）他の資金として、平成 12 年度教育改善推進費や重点化経費など、金沢大学か らの資金もあるが、予算規模に関しては筆者らは把握していない。

注7）このほかにも 2007 年度から県内の学生を対象として「里山里海リーダー養成 講座」を開講している。この取り組みでは、修了後、里山里海リーダーとして 認定されるとともに、自然体験活動推進協議会 (CONE) のリーダーとしても登 録され、石川県内で行われる自然体験活動での活躍が期待されている。2007 年 度は 7 名、2008 年度は 8 名が受講し、修了している。

注8）三井物産環境基金の支援のもと、石川県珠洲市の廃校になった小学校を拠点施 設として再生し、活動を展開している。現時点での活動日は不定期だが、自然 学校と同様に「里山里海メイト」を募集し、地域住民らとの協働活動を展開し ている。
注9）全学年を対象とした教養的科目の「ゼミ・角間の里山」である。授業は、平成 16 年度から始まっており、定時の開催だけではなく、市民とともに自然学校 の活動に参加する体験学習も組み込まれている。この科目の担当教員は、自然 学校の代表・事務局長をはじめとする全学の里山関係者によって構成されてお り、各担当者の専門分野が活かされた多様なプログラムとなっている。

\section{参考文献}

1）金沢大学「角間の里山自然学校」: 大学周辺の里山を活用した青少年等の学習プ ログラムの研究開発、平成 11 年度一 13 年度研究成果報告書

2）金沢大学「角間の里山自然学校」: 金沢大学角間キャンパス「里山ゾーン」を活 用した里山学習プログラムの研究開発、平成 14 年度一 16 年度成果報告書

3）金沢大学「角間の里山自然学校」: 金沢大学「角間の里山自然学校」を拠点とし た自然共生型地域づくり、平成 17 年度・18 年度成果報告書

4）小篠隆生・鶴崎直樹・小林英嗣 : キャンパスマスタープランからみた大学と地 域との連携の枠組みーカリフォルニア大学デイビス校とデイビス市の取り組み を事例として-、日本建築学会計画系論文集 第606 号、pp. 137-143、2006. 8

5）渡辺民代・塩崎賢明：アメリカのコミュニティ・デザイン・センターに関す る研究 歴史的発展過程と組織状況、日本建築学会計画系論文集 第 541 号、 pp. 139-146、2001. 3

6）渡辺民代・塩崎賢明：コミュニティ・デザイン・センターの組織構造と活動実 態 非営利型とボランティア型の場合、日本建築学会計画系論文集、第 556 号、 pp. 219-226、2002.6

7）近藤民代 : 全米大学の地域貢献活動実態と学生に対する参加型建築・まちづく りの専門家教育一大学ベース型のコミュニティ・デザイン・センターの活動実 態一、日本都市計画学会都市計画論文集、No. 39-3、pp. 337-342、2004. 10

8）遠藤新 : 大学に基盤を置く街づくりセンターの研究 米国の大学におけるデ ザインセンターの事例分析を通じて、日本建築学会技術報告集、第 20 号、 pp. 295-300、2004. 12

9）李彰浩 : 大学が主体となる大学まち再生に関する研究一米国におけるペンシル ベニア大学とその周辺地域を事例として一、日本建築学会計画系論文集、第 603 号、pp. 131-138、2006.5

10）中野大志他、参加型キャンパス環境マネジメント（PMCE）の実態と理論構築に 関する研究、日本建築学会大会学術講演梗概集 E-1、pp. 1131-1132、2006.9

11）中野大志他、参加型キャンパス環境マネジメント (PMCE) における協働ネットワー クの形成に関する研究、日本建築学会大会学術講演梗概集 F-1、pp. 1021-1022、 2007.8

\section{本研究関連の既発表論文}

1）高橋里佳・小松尚 : 大学・地域連携によるキャンパス緑地の保全・活用に関す る研究 一金沢大学角間の里山自然学校の活動を事例に一、日本建築学会大会学 術講演梗概集 F - 1 分冊（選抜梗概）、pp. 233-236、2008.9 